\title{
Chapter 13 \\ Incomplete Service Networks \\ in Enduring Socialist Housing Estates: \\ Retrospective Evidence from Local \\ Centres in Estonia
}

\author{
Kadri Leetmaa and Daniel Baldwin Hess
}

\begin{abstract}
Scholarly literature frequently refers to the incompleteness of service infrastructure in socialist housing estates. This has been considered a major failing of socialist residential landscapes that were planned and built according to scientific principles offering a high quality of life to residents through rational and technical design standards. This chapter presents visual and context-based evidence to illustrate how compromises in the service networks of newly built modernist housing estates were made during the socialist years. To do so, we investigate contemporaneous circumstances and decisions that delayed or (indefinitely) postponed the construction of neighbourhood services and community infrastructure. We ground our arguments in the evolution of Väike-Õismäe, a 1970s-era housing estate in Tallinn, Estonia. Findings suggest that even in one of the most admired residential districts, recognised with a prestigious architectural award from the Soviet state, the initial visions of the architect were unrealised and adjustments to plans were made in the earliest phases of implementation before construction began.
\end{abstract}

Keywords Housing estates - Mikrorayon - Socialism - Scarcity of resources • Service networks $\cdot$ Urban planning $\cdot$ Estonia

\footnotetext{
K. Leetmaa

Centre for Migration and Urban Studies, University of Tartu, Tartu, Estonia e-mail: kadri.leetmaa@ut.ee

D. B. Hess $(\square)$

Department of Urban and Regional Planning, University at Buffalo, State University of New York, New York, USA

e-mail: dbhess@buffalo.edu

(C) The Author(s) 2019

D. B. Hess and T. Tammaru (eds.), Housing Estates in the Baltic Countries,

The Urban Book Series, https://doi.org/10.1007/978-3-030-23392-1_13
} 


\subsection{Introduction}

Within the vast Soviet urbanisation programme between World War II and the late 1980s, a planned hierarchical system for creating rationalised townscapes was key to furthering the growth of socialist urban-industrial centres. There was an urgent need to address deficits in residential space in cities, and large modernist housing estates, designed with egalitarian principles as their foundation, were the response. The system provided highly subsidised apartments for Soviets in new standardised apartment buildings situated within carefully planned mikrorayons. The latter became the main 'building block' of socialist residential landscapes: all services were to be provided at prescribed walking distances to offer supreme efficiency and high quality of life.

It is widely agreed, however, that in socialist cities, the service networks were only partially provided relative to the prescribed levels in initial visions. A failure to provide living environments with ample modern conveniences is seen as one of the major failings of socialist housing estates. This is usually attributed to the crushing demand for building new housing units elsewhere in the city, because services came to be viewed as noncritical amenities that could be added later. Consequently, housing estates almost never reached their full functional potential. Although scholarly literature frequently refers to this reality, these arguments tend to remain vague and abstract without clearly demonstrating how mikrorayon service networks evolved during the planning, construction and occupation of new estates.

The ambition of this chapter is to bring more clarity and visual analysis to these statements. The article focuses on a 1970s-era residential district, Väike-Õismäe (Little Blossom Hill in translation) in Tallinn, Estonia. As this chapter is written, Väike-Õismäe celebrates its 50th anniversary (its first detailed plan was approved in 1968). Although we present Väike-Õismäe as an archetypical incomplete housing estate, it received the Soviet State Architectural Award in 1986, a recognition that only a few districts achieved in the entire Soviet Union.

Archival documents and images, written debates among architects and opinion leaders in the 1970s, other texts written by the key planners of Soviet Estonia during socialist years and later, and a retrospective interview (carried out in 2017) with the former (1960-1980) Chief Architect of Tallinn are used to trace how the services were planned and implemented.

\subsection{Planned Residential Districts in Socialist Cities}

Centrally planned systems and government ownership of all land in the Soviet Union made possible a unified vision of urbanisation and its on-the-ground realisation. The economy was meticulously planned by central authority (Hegedüs and Tosics 1983) to reach the industrial ambitions of fast-growing cities. Public provision of housing and carefully designed residential districts were intended to be a 
vital aspect of the socialist regime. A remarkable share of pre-World War II housing stock was destroyed during the war; after nationalisation, many people resided in inadequate conditions in communal apartments (Tsenkova 2009) and explosive industrial growth worsened the situation. Housing systems became firmly embedded in larger political and economic structures in the socialist regime (Marcuse 1996; Liepa-Zemeša and Hess 2016). It was believed that equally high living standards for all residents could be achieved through central planning. The universal right for housing was even written in the Soviet Constitution.

Town planning was performed by trained architects (Wright 1958) during Soviet times. Architects employed by the government at various levels (in state bureaus, municipal governments, design institutes in republics) sought to establish integrated residential districts designed to cleverly rationalise internal organisation of cities. A primary component of the spatial organisation of socialist cities was a pre-fabricated apartment building. Apartment buildings were to be aggregated into standardised units known as mikrorayons, envisioned as self-contained neighbourhoods. In theory, mikrorayons could house 5,000-9,000 people focused around an elementary school (Perry 1926; Bruns 2007, 34). Mikrorayons were in turn aggregated to produce larger planned housing estate districts (even for 100,000 or more residents) (Bater 1980; Miliutin 1974; Robinson 2009; Smith 1996; Stanilov 2007). The districts were mostly located on greenfields on the urban periphery. Although the ambition was to replace the entire urban housing stock with modern apartments, a permanent shortage of dwellings prohibited the demolition of older quarters (Hess and Hiob 2014).

Ideologies supporting modernist residential planning 'travelled' from country to country in the early and mid-twentieth century (Dahir 1947; White 1980). In the Soviet Union, planning for mikrorayons borrowed principles from British new towns (Kaufmann 1936; Goss 1961), planned unit developments in the United States (Perry 1929, 1926), and Scandinavian tower-in-the-forest suburban settlements (Cinis et al. 2008). Travel reports and books written by young Soviet architects who later became key figures in designing modernist housing areas in Soviet Estonia (Port 1966) suggest that Soviet architects had professional ties with their Western colleagues (Shenker 1971). The usual spatial organisation of the districts followed a superblock approach and incorporated the principle of co-mingling housing and services, thereby exploiting proximity opportunities by creating neighbourhoods which stressed accessibility (and a scientific approach for ensuring minimum distances) (Hall 1988; Lu 2006).

A key element of spatial plans of modernist mikrorayons was the provision of green space. Green buffer areas were intended to enclose industrial zones and delineate housing estate districts. It has been argued that in socialist cities, such open space would allow for even 'more recreational opportunities than in capitalist cities’ (Hall 1987, p 263). In addition, an organised system of pathways provided walking access for commuting to work, to schools, to service, commercial and leisure centres, and to public transport stations (Obraztsov 1961). Importantly, green areas and pathways, and traffic relegated to perimeters of mikrorayons 
provided apartment dwellers with convenient walking access to community resources and safe environments for children to walk and play unaccompanied.

Within the building process, the design of building elements, including wall panels, stairways, and doors, was standardised through industrial processes. This was the most rational solution for building quickly and in large quantities. The components were manufactured in factories and assembled on-site. Mechanisation delivered completed tower blocks which were at first unsophisticated; with maturation of the programme, however, complete mikrorayons (standard projects for apartment blocks but also for mikrorayon service centres) were industrially produced (Andrusz 1984). Uniformity and disciplined repetition-with a reduced role for artistry and organicism in design - produced an identical and anonymous built environment (Hatherley 2016; Monclús and Díez Medina 2016). We demonstrate that although architectural uniformity was deemed necessary to support equality, the criticism towards regularity of built structures began to emerge immediately after the first mikrorayons were erected.

\subsection{Service Networks Offer Function and Convenience}

Each mikrodistrict will have one school, two pre-school children's establishments, a food shop, a personal service shop, a cafeteria, club, and building maintenance office. Here the radius of servicing does not exceed 400 meters (Obraztsov 1961, p 35).

When standardisation in planning and housing construction started to gather momentum in socialist cities, the mikrorayon approach was widely discussed among urban experts. The prime qualities to be offered were 'access' and 'proximity' to services and daily necessities and 'efficiency' in urban mobility. The number and type of services provided were precisely calculated (or, in socialist parlance, 'allocated') by administrators based on per-capita standards (DiMaio 1974; French and Hamilton 1979). This (scientific) approach was considered an improvement over organic demand-based appearance of services, offering $20 \%$ efficiency savings over traditional organisation of street space (Obraztsov 1961).

Community services were located in the most interior space of mikrorayons, segregating playgrounds and outdoor socialisation space from vehicle traffic. Most important was that the schools were situated at a walkable distance and walking paths were safe. In Soviet Estonia, the double-mikrorayon concept for 12,000 inhabitants and 2 schools was implemented; due to immigration, Estonian cities became bilingual and a mikrorayon needed to contain both an Estonian and Russian language school (Leetmaa 2017, interview with Dmitri Bruns).

Services were organised hierarchically into 'layers' (Marozas 2009) with everyday needs located conveniently for the residents of one mikrorayon, and higher order services walkable or accessible via public transport for several mikrorayons (Hess 2018). Each residential district should have a planned main or 
higher order centre. Within approximately 400 metres from every residence, an everyday service centre ('ABC centre') had to be located (Obraztsov 1961). Services visited less frequently-department stores, health clinics, cinemas, social clubs, a House of Culture-were planned for the main centre, still saving residents from a need to travel regularly to the city centre.

Naturally, given the cost of providing community facilities, Soviet architects were expected to provide the smallest amount of services possible and still satisfy norms. The multilayered plan for service networks called for designing appropriate mikrorayon service centres. The latter usually contained pavilions and one- to two-storey low-rise buildings set in a walkable environment. Besides functionality, the sculptures, fountains, and benches were part of the spatial composition of centres suggesting that this designed space should be used for meeting and socialising (Šiupšinskas and Lankots 2019). The Baltic architects gathered inspiration for service centre design from multifunctional satellite settlements surrounding Nordic capitals_-Vällingby (Stockholm, Sweden) and Tapiola (Helsinki, Finland) - that they visited on state-sponsored study trips (Metspalu and Hess 2018; Šiupšinskas and Lankots 2019). In reality, even when architects proposed original concepts for mikrorayon centres, budget pressures often caused the simplification and standrdisation of public buildings.

\subsection{Service Networks Fall Short of Promises}

Although convenient access - to consumer services, healthcare, education, and recreation - served as a founding principle for mikrorayons, new districts were in practice often poorly equipped with services (Gentile and Sjöberg 2006; Hausladen 1987; Kalm 2012; Svetlichnyi 1960; Temelová et al. 2011; Cinis et al. 2008). A significant share of the service component was delayed or never built (De Decker and Newton 2009; Gentile 2004; Sjöberg 1992). For this reason, the Soviet urban experience differed significantly from idealistic visions.

During the implementation of carefully drawn plans for housing estates, service networks were viewed as providing noncritical amenities and secondary to the raison d'etre of mikrorayons: to provide housing for industrial workers (DiMaio 1974). A general expectation existed that after a higher welfare level is achieved in the future, society will be positioned to enrich all aspects of citizens' lives. From a practical point of view, the provision of housing and services were the responsibilities of different ministries, and the funding for these tasks came from separate budgets and was typically uncoordinated (Bruns 2007, 38).

To compensate for an absence of nearby neighbourhood services, residents adapted and managed their daily needs in other ways; for example, they used existing, often overloaded, infrastructure of neighbouring residential districts. But this could be challenging since the planned public transport connections with the rest of the city were also unfinished (Hess 2017). Usually, only schools and child care facilities were developed in accordance with initial plans (Bruns 2007, 39); 
grocery stores, retail outlets, health clinics, catering, cultural and household service establishments, however, significantly lagged behind the plans (Shaw 1991). Consequently, even when ambitious plans for service networks helped to justify peripheral locations for new residential districts, housing estate residents still remained dependent, out of necessity, on city centres.

Plans for the socialist-era expansion of Tallinn confirm that all larger housing estate districts were designed to have one main centre, while embedded mikrorayons would also have a commercial centre; in reality, none of the higher order centres was built. Delays in providing planned services and often indefinite postponements of establishing mikrorayon centres were endemic to all socialist cities. Next, we present the story of Väike-Õismäe district in Tallinn to illustrate these tendencies with visual materials and description of circumstances and decisions made at the time the district was planned and constructed.

\subsection{Väike-Õismäe-An Unfinished Macrorayon}

\subsubsection{The Mikrorayon Takes Shape as a Planning Unit}

In Tallinn, then the capital of the Estonian Soviet Republic, mass housing construction was launched in the late 1950s. After Khrushchëv criticised excess in residential construction, housing construction became increasingly industrialised in the Soviet Union. In the late 1950s and early 1960s, standard apartment buildings using brick construction, khrushchëvki, were built in small groups as in-fill in unbuilt or war-demolished areas relatively close to city centres. The advantages of using factory produced panels and standard building projects were soon realised. The first pilot panel buildings were erected in Tallinn in 1961 and the practice quickly became prevalent.

In urban planning the mikrorayon concept was gradually adopted in the same period. In the first larger modernist districts of Soviet Tallinn (Pelguranna, built in the late 1950s) apartment buildings were arranged in rows, not closed yards, and service networks were less developed. In the 1960s, when Mustamäe housing estate district was built (preceding Väike-Õismäe district), the mikrorayon approach had already become prevalent in residential planning. Mustamäe consisted of nine mikrorayons in which the principles of self-contained neighbourhoods were followed.

According to the General Plan of Tallinn (adopted in 1968), after Mustamäe was constructed, the focus of residential construction should shift to Väike-Õismäe, situated atop bare agricultural land in the western part of the city (Bruns 1993, 148150). By that time the mikrorayon concept had been practiced throughout the Soviet Union for 10 years. Originally, Väike-Õismäe district, with three mikrorayons, was intended to become a logical continuation of the adjacent Mustamäe mikrorayons. The planning process of Väike-Õismäe, however, elevated the mikrorayon concept to a new level. 


\subsubsection{From Mikrorayon to Makrorayon: Initial Planning Task for Väike-Öismäe}

The official planning task for Väike-Õismäe district was issued in 1967. The idea was to plan a housing estate at the intersection of two main streets (Paldiski and Ehitajate roads) (Fig. 13.1). The Tallinn Executive Office for Architecture and Planning commissioned Eesti Projekt, the central planning institute of the republic, to compile the detailed plan of Väike-Õismäe. The draft plans submitted by the planning team (lead architect Mart Port with collaborators Malle Meelak, Kalju Luts and Inessa Põldma) included four alternative versions of spatial plans for mikrorayons in VäikeÕismäe (Fig. 13.2). The team preferred an innovative solution that formed a single large integrated makrorayon rather than three separate mikrorayons (Fig. 13.2, image 3). The prime reason for this decision stemmed from consideration for the location of the new district: planners feared that vehicular traffic would take shortcuts between Ehitajate and Paldiski road; large traffic flows, however, were not intended to drive through housing estates. To avoid this, a circular street connecting mikrorayons but not enabling through traffic was proposed.

The planners demonstrated that important elements of the mikrorayon concept were achievable in the makrorayon configuration. Three major commercial and service centres were placed at the outer corners of the circular street; these, together with smaller groceries, had to ensure that the walking distance from homes to shops and service points would not exceed 550 metres. Public transport would function circularly to ensure that bus stops are close to service centres and homes.

The full detailed plan of Väike-Õismäe was submitted to the city administration in Spring 1968, after which it had to travel through the approval process of various republic and city departments. Somewhat surprisingly, the innovative spatial approach was welcomed rather warmly by the bureaucracy of Soviet Estonia, and the first detailed plan of the district was approved in late 1968 (Fig. 13.3). The shift from mikrorayon to makrorayon is reflected in the handwritten revisions made throughout the typed manuscript of the 1968 Detailed Plan: the word 'mikrorayons' (plural) has been replaced with the word 'makrorayon' (singular).

The 9-storey residences were located inside the circular street and 5-storey buildings were located outside of it. Taller towers added visual accents: single 16-storey apartment towers were placed between 9-storey apartment buildings, and 22-storey apartment towers demarcated the location of service centres outside the circular road. The 1968 plan also proposed a small number of 1-storey and 2-storey residential buildings. These smaller buildings were to be financed through cooperative housing funding schemes. By introducing various building heights, planners aimed to bring variety into an otherwise monotonous area. They also proposed to introduce more innovative individual building projects or at least new standard projects for towers, schools and kindergartens, and service centres.

The area within the circular street was designed for children and recreation. In the middle of the green pedestrian park, an artificial pond surrounded by a 


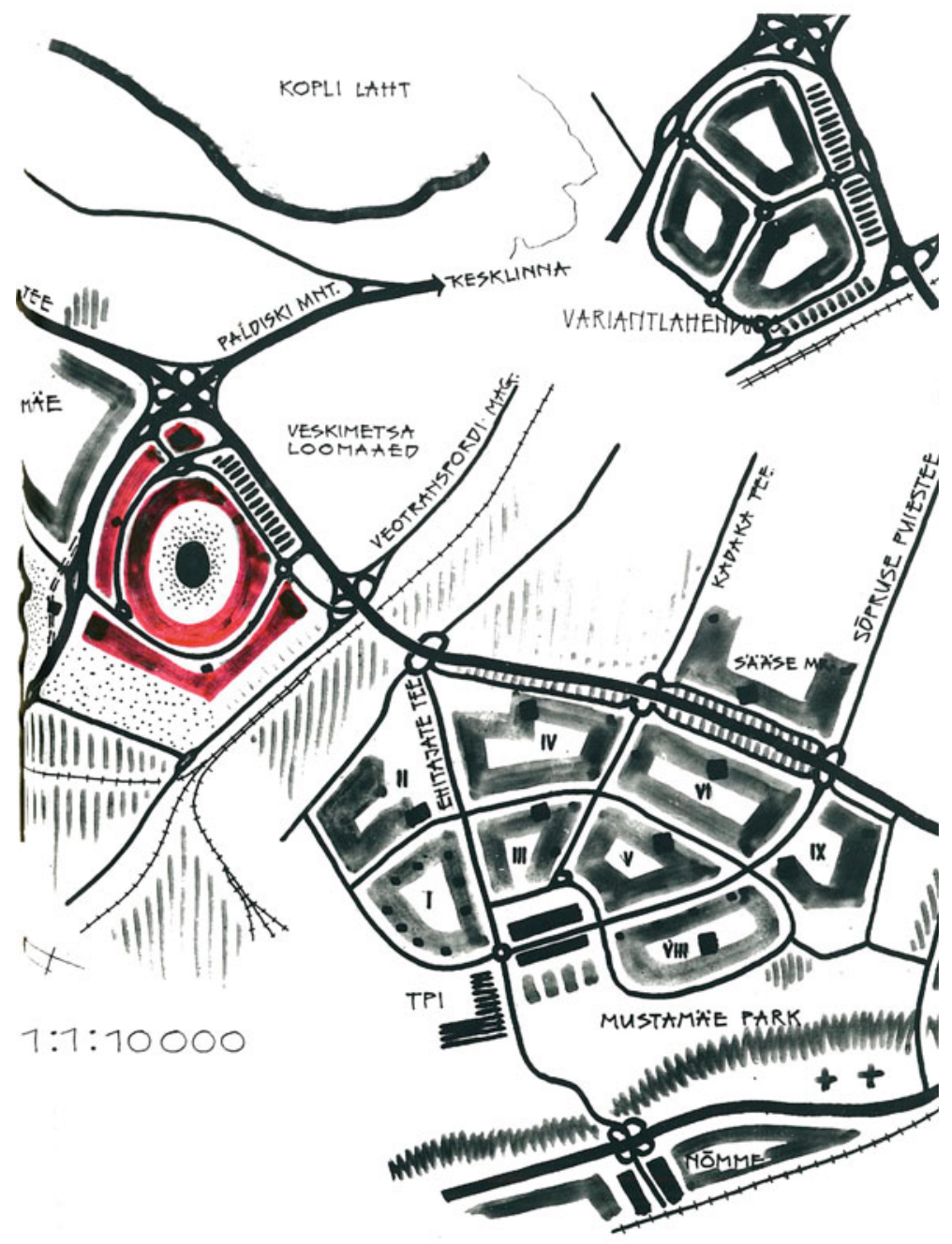

Fig. 13.1 Location of Väike-Õismäe district, 1968 detailed plan Source Archive of the Tallinn city planning department. Used with permission 


\section{Variantlahenduste arhitekturursed skeemid}

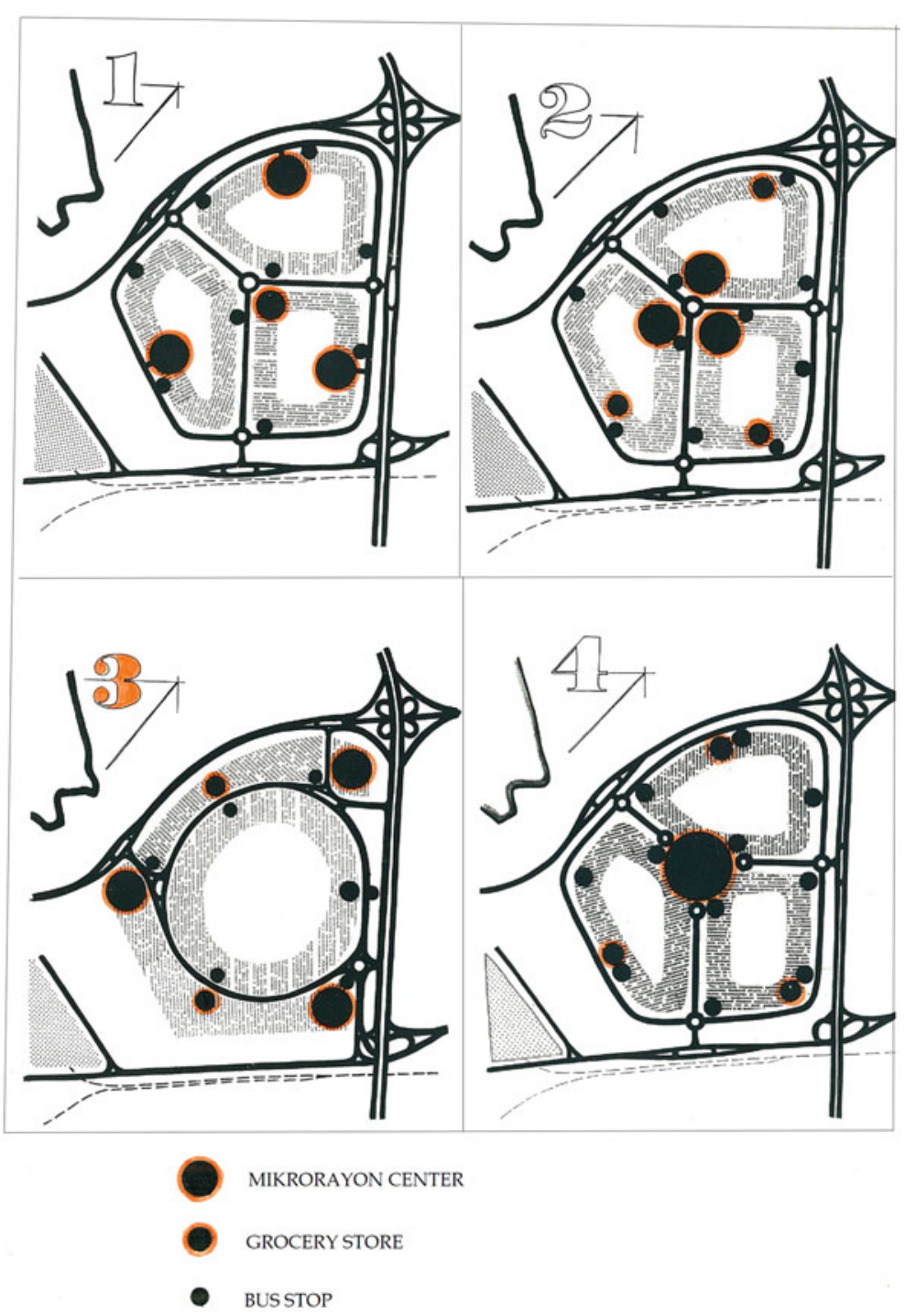

Fig. 13.2 Four alternative configurations of Väike-Õismäe housing estate, 1968 detailed plan Source Archive of the Tallinn city planning department. Used with permission

'sunbathing lawn' was planned. All four schools (both Estonian and Russian schools) and kindergartens (10 buildings), alternating with small car-free parks and play areas, were inside the circle. In this way, most school-age children, except 


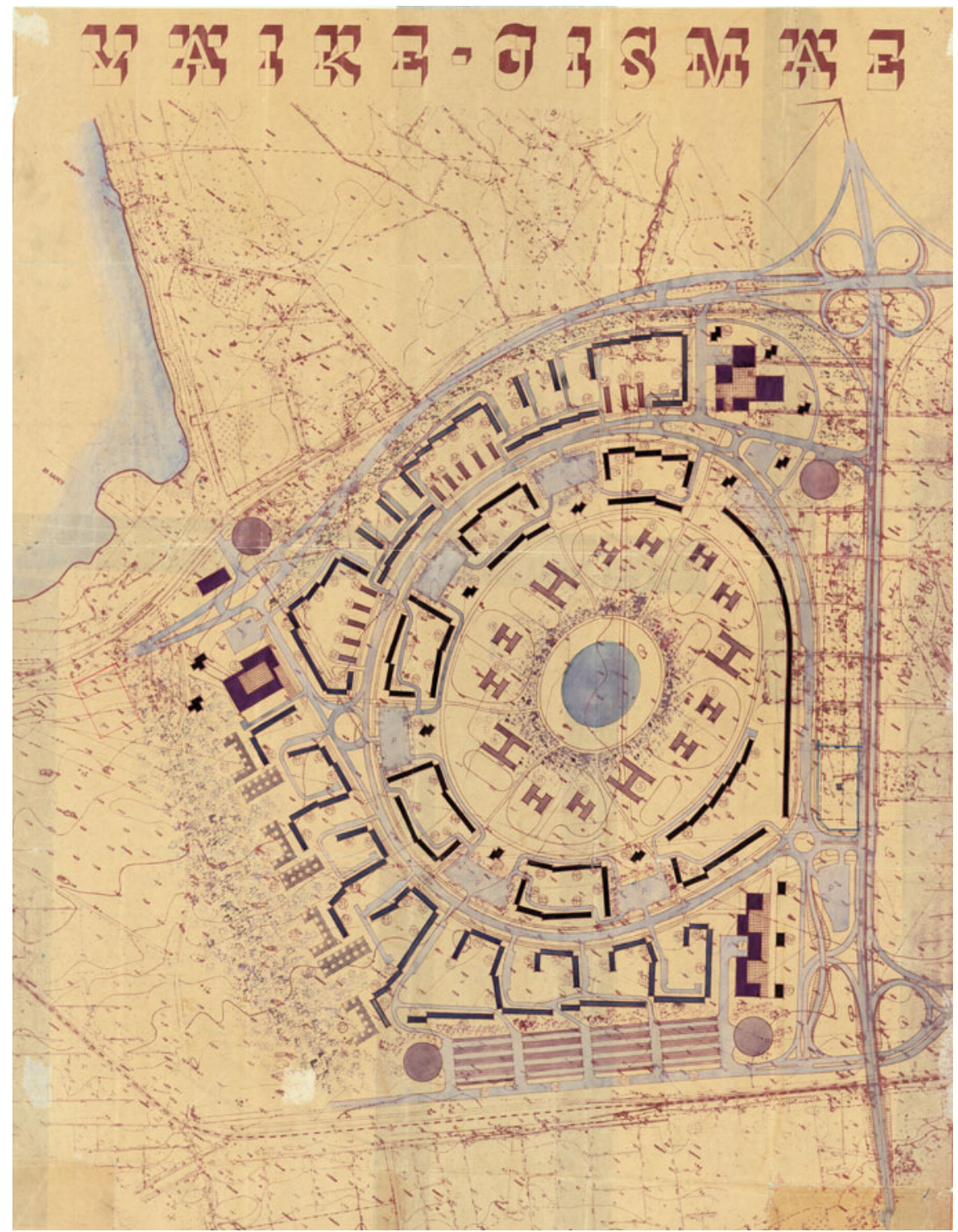

Fig. 13.3 General planning scheme of Väike-Õismäe, 1968 detailed plan Source Tallinn city planning department archive. Used with permission

those living outside the circular street, could walk to schools without crossing major streets. This was also one of the few critical points that was highlighted by city and state administrations: an alternative was to place some schools outside the circle. 


\subsubsection{Planned Service Network of the 1968 Detailed Plan}

The district as a whole had to meet similar norms and quality standards as other housing estates consisting of mikrorayons. The initial detailed plan of 1968 proposed three service centres: Centre No. 1 in the corner where Paldiski and Ehitajate roads intersect; Centre No. 2 in the corner adjacent to Mustamäe; Centre No. 3 close to Harku Lake. All three major service centres were located outside of the circular main street. The centres were more or less located symmetrically at equal distances from each other; to ensure the proximity of a convenience store to all residences, three auxiliary groceries were placed between these centres.

The 1968 Detailed Plan carefully prescribes the composition of the service centres. Table 13.1 presents the planned service network. Centre No. 1 became the main centre where higher order services important to the entire Väike-Õismäe district were envisioned.

Naturally, the construction process had to start somewhere. The 1968 plan suggested the initial construction order to enable habitation of the first parts of the district while subsequent construction occurred. Certain buildings had to be erected first: two courtyards with 9-storey and grouped 5-storey residential buildings, one school, three kindergartens and one of the planned service centres. Interestingly, Centre No. 2 became the first that was built. The rationale to start construction activities in this sector of the new district was its proximity to Mustamäe. Although Mustamäe was not yet finished, its infrastructure and utilities could be used; for example, the initial dwellings in Väike-Õismäe could temporarily be heated from boilers from Mustamäe (until the heating system for Väike-Õismäe was complete).

In reality, major investments related to the physical preparation of the construction site became the prerequisites without which housing construction could not be launched in Soviet Tallinn. The first Väike-Õismäe plan paid a great deal of attention to infrastructure: power supply, central heating, water, sewage, and stormwater sewers. It was clearly stated, for example, that construction in VäikeÕismäe could not begin before sewage collector No. 3 had been installed.

Housing construction was scheduled to begin in Väike-Õismäe in 1971. This was postponed, however, due to unexpected technical obstacles (especially challenges with soil conditions) that appeared during the early stages of water and sewage system installation. Consequently, construction of Väike-Õismäe was postponed to 1973. As the centralised construction industry could not be stalledbuilding factories in Tallinn produced building components for housing estates at top production-two mikrorayons (Siili and Sääse) were spontaneously erected near existing parts of Mustamäe, and Mustamäe itself was densified with more apartment buildings, even though the service networks of Mustamäe were still unfinished. 
Table 13.1 Composition of Väike-Õismäe service centres according to the 1968 detailed plan

\begin{tabular}{|c|c|c|c|c|}
\hline Type of service & $\begin{array}{l}\text { Centre no 1. Main } \\
\text { centre (Paldiski Road) }\end{array}$ & $\begin{array}{l}\text { Centre no. } 2 . \\
\text { (Ehitajate } \\
\text { Road) }\end{array}$ & $\begin{array}{l}\text { Centre No. } 3 . \\
\text { (Lake Harku/ } \\
\text { Järveotsa) }\end{array}$ & Total \\
\hline Pharmacy & 1 & 1 & 1 & 3 \\
\hline $\begin{array}{l}\text { Milk supply } \\
\text { station }\end{array}$ & 1 & 1 & 1 & 3 \\
\hline $\begin{array}{l}\text { Club rooms and } \\
\text { library }\end{array}$ & 200 visitors & 200 visitors & 200 visitors & $\begin{array}{l}600 \\
\text { visitors }\end{array}$ \\
\hline $\begin{array}{l}\text { Widescreen } \\
\text { cinema }\end{array}$ & 600 visitors & - & - & $\begin{array}{l}600 \\
\text { visitors }\end{array}$ \\
\hline Canteen & $\begin{array}{l}200 \text { visitors } \\
\text { (usable as café } \\
\text { restaurant in the } \\
\text { evenings) }\end{array}$ & 100 visitors & 100 visitors & $\begin{array}{l}400 \\
\text { visitors }\end{array}$ \\
\hline Grocery stores & 25 employees & 25 employees & 25 employees & $\begin{array}{l}75 \\
\text { employees }\end{array}$ \\
\hline $\begin{array}{l}\text { Industrial good } \\
\text { stores }\end{array}$ & 4 employees & 4 employees & 4 employees & $\begin{array}{l}12 \\
\text { employees }\end{array}$ \\
\hline $\begin{array}{l}\text { Housing } \\
\text { administrative } \\
\text { office }\end{array}$ & 1 & 1 & 1 & 3 \\
\hline Shoe repair & 25 employees & - & - & $\begin{array}{l}25 \\
\text { employees }\end{array}$ \\
\hline Tailor & 68 employees & - & - & $\begin{array}{l}68 \\
\text { employees }\end{array}$ \\
\hline Photography & 3 employees & - & 2 employees & $\begin{array}{l}5 \\
\text { employees }\end{array}$ \\
\hline $\begin{array}{l}\text { Metal equipment } \\
\text { and clock repairs }\end{array}$ & 15 employees & - & - & $\begin{array}{l}15 \\
\text { employees }\end{array}$ \\
\hline Hairdressers & 20 employees & 5 employees & 5 employees & $\begin{array}{l}30 \\
\text { employees }\end{array}$ \\
\hline Rental station & - & - & 1 employee & $\begin{array}{l}1 \\
\text { employee }\end{array}$ \\
\hline $\begin{array}{l}\text { Laundry } \\
\text { reception desk }\end{array}$ & 1 employee & 1 employee & 1 employee & $\begin{array}{l}3 \\
\text { employees }\end{array}$ \\
\hline $\begin{array}{l}\text { Dry cleaner } \\
\text { reception desk }\end{array}$ & 1 employee & 1 employee & 1 employee & $\begin{array}{l}3 \\
\text { employees }\end{array}$ \\
\hline $\begin{array}{l}\text { Self-service } \\
\text { laundry }\end{array}$ & 1 employee & 1 employee & 1 employee & $\begin{array}{l}3 \\
\text { employees }\end{array}$ \\
\hline Sauna & 200 visitors & - & - & $\begin{array}{l}200 \\
\text { visitors }\end{array}$ \\
\hline $\begin{array}{l}\text { Service bureau } \\
\text { office }\end{array}$ & 1 employee & - & - & $\begin{array}{l}1 \\
\text { employee }\end{array}$ \\
\hline $\begin{array}{l}\text { Telephone central } \\
\text { station }\end{array}$ & - & 1 & - & 1 \\
\hline
\end{tabular}

Source Tallinn city planning department archive 


\subsubsection{The 1974 Revision of Väike-Õismäe Detailed Plan and the Construction Process}

For some years, the 1968 Detailed Plan of Väike-Õismäe stood at a standstill. In 1973, in parallel with the beginning of housing construction, a new planning task was issued for the 'Revision' of the initial detailed plan. This was partly related to fast modernisation: more automobile parking and more landline telephone connections were needed. In many aspects, the plan also needed greater specification. For example, the purpose of the central plan was not clarified in the 1968 plan: should it be possible to swim there, and how it should be regularly cleaned and supplied with water? The important decisions were needed about pedestrian safety while crossing the circular street. Most importantly, however, a final executive decision was needed about which projects to finance and in which order. The project in Väike-Õismäe demonstrates the need for a realistic programme that clarifies what to build, what not to build, and what to postpone. This need emerged very early during construction.

Low-rise buildings were left out of implementation plans without discussion (Table 13.2), even though they nicely diversified the housing composition of the area, since it was understood that 1- and 2-storey buildings would not help solve housing shortages. Nonetheless, Väike-Õismäe was envisioned to have a diverse cityscape due to its varying building heights.

A general principle was that Väike-Õismäe should accommodate more living space than originally envisioned in the 1968 plan. Additional land was allocated for housing construction (Fig. 13.4). Initially, the area outside the circular road between Centres No. 1 and 2 was reserved for small enterprises (for adding more services and jobs in the future), but in the revised plan this area included 5-storey apartment buildings. West of the makrorayon, additional housing was planned that included educational facilities and formed a separate mikrorayon (likely following the advice of some experts in 1968 that certain educational buildings should also be placed

Table 13.2 Comparison of housing composition, 1968 detailed plan and 1974 revision

\begin{tabular}{l|l|l}
\hline \multirow{2}{*}{} & \multicolumn{2}{l}{$\begin{array}{l}\text { Living space, sq. m (share of total housing } \\
\text { stock) }\end{array}$} \\
\cline { 2 - 3 } & 1968 detailed plan & 1974 revision \\
\hline 1-storey houses & $3,840(1.1 \%)$ & - \\
\hline 2-storey apartment buildings & $7,040(1.9 \%)$ & - \\
\hline 5-storey apartment buildings & $135,725(38.0 \%)$ & $138,429(34.7 \%)$ \\
\hline 9-storey apartment houses & $165,218(46.3 \%)$ & $196,727(49.4 \%)$ \\
\hline 16-storey towers & $45,000(12.7 \%) *$ & $43,355(10.9 \%)$ \\
\hline 22-storey towers & & $20,000(5.0 \%)$ \\
\hline Total & $356,823(100.0 \%)$ & $398,511(100.0 \%)$ \\
\hline
\end{tabular}

Source Tallinn city planning department archive

Note 16- and 22-storey apartment buildings are not differentiated 


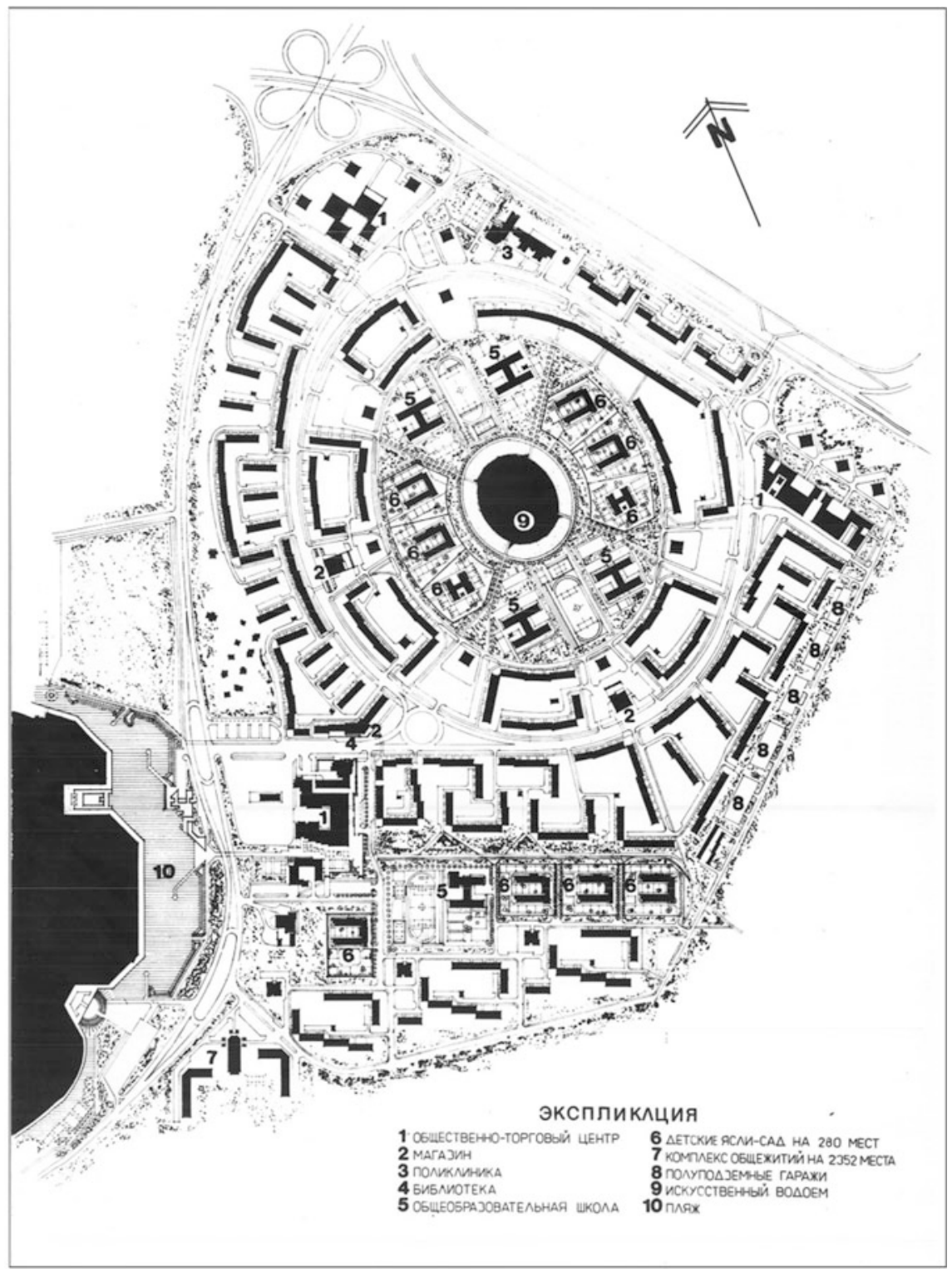

Fig. 13.4 General plan of Väike-Õismäe district, 1974 revision plan Source Tallinn city planning department archive. Used with permission

outside the circle). Although 10 kindergartens and 4 schools were initially planned in the pedestrian park, the revised plan included 6 kindergartens and 4 schools within the circle (making the pedestrian park less dense). Four more kindergartens and 1 school were allocated to the new mikrorayon. 
The most relevant compromises were made in service networks. In order to adapt to changes, a new service network was proposed (Table 13.3) in which services in the planned main centre were substantially reduced. Some services were moved to other locations, other service centres, or elsewhere on undeveloped land. The hierarchical principle that service centre No. 1 should be a higher order centre now disappeared. The most important services in Väike-Õismäe, however, had to be built somewhere. A public sauna, intended to be part of Väike-Õismäe centre No. 1 was shifted to the category 'outside the service centres' (Table 13.3), and specific sizes were indicated for small shops 'outside the service centres' (these were the planned auxiliary groceries allocated between service centres in 1968). Clearly, a more realistic plan was created because residents had by then started to move in and needed primary services.

The 1974 Revision modernised, complemented, and specified the initial detailed plan. A district fire station, a service station for buses and trolleybuses, and a policlinic were added to the district plan, locating them outside the service centres. Experts were invited to analyse whether and how to build the pond. Visually it was attractive, but when the start of construction approached, critics argued that Tallinn is a coastal town and digging artificial ponds is ridiculous. An interesting discussion unfolded: architects argued that Tallinn has positive experiences in integrating artificial water with urban design, referring to the eighteenth century Kadriorg castle and park. (Socialist housing estates surprisingly were compared with classical architecture.) The final decision to construct the pond was related to the rationality arguments: planners demonstrated that the soil from the pond area could be used in a cost-saving way as fill on housing construction sites.

A debate unfolded in relation to pedestrian safety and more specifically, how the circular street should be crossed. In the 1970s, urban planning principles were constantly refined. In Lasnamäe, a Tallinn housing estate area that was in the planning phase when the construction work in Väike-Õismäe was underway, pedestrians were separated from motorised traffic through physical design. The revision of Väike-Õismäe plan was sent back several times to the planners' desk with the requirement to address pedestrian crossings with bridges or tunnels (instead of pedestrian safety islands and zebra crossings). 'Planners argued that the proposals were expensive and it was too late to introduce new configurations when preparatory work had already been finished. The final decision was that, if needed, traffic signals would be installed at critical spots.

The housing construction of Väike-Õismäe indeed started in the nearest corner of Mustamäe, and Centre No. 2 was built along with the first buildings. As expected, and similar to all other housing estate districts in Tallinn, the planned main Centre No. 1 was never started. The construction of housing in Väike-Õismäe occurred between 1973 and 1978. During this period, two auxiliary groceries (a planning strategy for reducing walking distances for those living further from proper centres) were finished on the plots reserved for parking.

At the same time, the centres were renumbered in order to give an impression of completeness. Figure 13.5 shows one of the small groceries that now (instead of the main centre) was numbered as 'Õismäe 1'. Centre No. 2 in the initial plan now was 
Table 13.3 Composition of Väike-Õismäe service centres, 1974 revision plan

\begin{tabular}{|c|c|c|c|c|c|}
\hline Type of service & $\begin{array}{l}\text { Centre No. } 1 . \\
\text { Main centre } \\
\text { (Paldiski Road) }\end{array}$ & $\begin{array}{l}\text { Centre } \\
\text { No. } 2 . \\
\text { (Ehitajate } \\
\text { road) }\end{array}$ & $\begin{array}{l}\text { Centre No. } 3 . \\
\text { (Lake Harku/ } \\
\text { Järveotsa }\end{array}$ & $\begin{array}{l}\text { Outside } \\
\text { planned } \\
\text { service } \\
\text { centres }\end{array}$ & Total \\
\hline Pharmacy & 1 & 1 & 1 & - & 3 \\
\hline $\begin{array}{l}\text { Milk supply } \\
\text { station }\end{array}$ & 1 & 1 & 1 & - & 3 \\
\hline $\begin{array}{l}\text { Widescreen } \\
\text { cinema }\end{array}$ & 600 visitors & - & - & - & 600 visitors \\
\hline $\begin{array}{l}\text { Canteen, } \\
\text { restaurant }\end{array}$ & 200 visitors & $\begin{array}{l}180+30 \\
\text { visitors }\end{array}$ & 100 visitors & - & 510 visitors \\
\hline Grocery stores & $650 \mathrm{~m}^{2}$ & $710 \mathrm{~m}^{2}$ & $650 \mathrm{~m}^{2}$ & $\begin{array}{l}300+300+ \\
300 \mathrm{~m}^{2}\end{array}$ & $2910 \mathrm{~m}^{2}$ \\
\hline $\begin{array}{l}\text { Industrial good } \\
\text { stores }\end{array}$ & $300 \mathrm{~m}^{2}$ & $\begin{array}{l}4 \\
\text { employees }\end{array}$ & 4 employees & $500 \mathrm{~m}^{2}$ & $\begin{array}{l}4 \\
\text { employees }+800 \\
\mathrm{~m}^{2}\end{array}$ \\
\hline $\begin{array}{l}\text { Housing } \\
\text { administrative } \\
\text { office }\end{array}$ & 1 & 1 & 1 & - & 3 \\
\hline $\begin{array}{l}\text { Militia (internal } \\
\text { affairs) and } \\
\text { passport office }\end{array}$ & 1 & - & - & - & 1 \\
\hline Shoe repair & 25 employees & $\begin{array}{l}2 \\
\text { employees }\end{array}$ & - & - & 27 employees \\
\hline Tailor & 67 employees & - & - & - & 67 employees \\
\hline Photography & 3 employees & - & 2 employees & - & 5 employees \\
\hline $\begin{array}{l}\text { Metal } \\
\text { equipment, } \\
\text { clock repair }\end{array}$ & 15 employees & - & - & - & 15 employees \\
\hline $\begin{array}{l}\text { Metal } \\
\text { equipment, } \\
\text { clock repair } \\
\text { (reception) }\end{array}$ & - & $\begin{array}{l}2 \\
\text { employees }\end{array}$ & - & - & 2 employees \\
\hline Hairdressers & 18 employees & $\begin{array}{l}5 \\
\text { employees }\end{array}$ & 5 employees & - & 28 employees \\
\hline Rental centre & - & 1 & - & - & 1 \\
\hline $\begin{array}{l}\text { Service bureau } \\
\text { office }\end{array}$ & $50 \mathrm{~m}^{2}$ & - & - & - & $50 \mathrm{~m}^{2}$ \\
\hline $\begin{array}{l}\text { Laundry } \\
\text { reception desk }\end{array}$ & 1 & 1 & 1 & - & 3 \\
\hline $\begin{array}{l}\text { Dry cleaner } \\
\text { reception desk }\end{array}$ & 1 & 1 & 1 & - & 3 \\
\hline $\begin{array}{l}\text { Self-service } \\
\text { laundry }\end{array}$ & 1 & - & - & - & 1 \\
\hline $\begin{array}{l}\text { Post office, } \\
\text { bank }\end{array}$ & 1 & 1 & 1 & - & 3 \\
\hline
\end{tabular}


Table 13.3 (continued)

\begin{tabular}{l|l|l|l|l|l}
\hline Type of service & $\begin{array}{l}\text { Centre No. 1. } \\
\text { Main centre } \\
\text { (Paldiski Road) }\end{array}$ & $\begin{array}{l}\text { Centre } \\
\text { No. 2. } \\
\text { (Ehitajate } \\
\text { road) }\end{array}$ & $\begin{array}{l}\text { Centre No. 3. } \\
\text { (Lake Harku/ } \\
\text { Järveotsa }\end{array}$ & $\begin{array}{l}\text { Outside } \\
\text { planned } \\
\text { service } \\
\text { centres }\end{array}$ & Total \\
\hline $\begin{array}{l}\text { Urban } \\
\text { sanitation office }\end{array}$ & - & 1 & - & - & 1 \\
\hline Public toilet & 1 & 1 & 1 & - & 3 \\
\hline Health clinic & - & - & - & $\begin{array}{l}1(1600 \\
\text { patients per } \\
\text { day) }\end{array}$ & 1 \\
\hline Newsstands & 2 employees & 3 & 1 employees & 2 employees & 8 employees \\
\hline Flower shop & - & 1 & - & - & 1 \\
\hline $\begin{array}{l}\text { Bus stop } \\
\text { pavilions }\end{array}$ & 1 & 1 & 1 & 1 & 4 \\
\hline Fire station & - & - & - & 1 & 1 \\
\hline $\begin{array}{l}\text { Public transport } \\
\text { service station }\end{array}$ & - & - & - & 1 & 1 \\
\hline $\begin{array}{l}\text { Telephone } \\
\text { central station }\end{array}$ & - & - & - & 1 & 1 \\
\hline Sauna & - & - & - & 300 visitors & 300 visitors \\
\hline
\end{tabular}

Source Tallinn city planning department archive

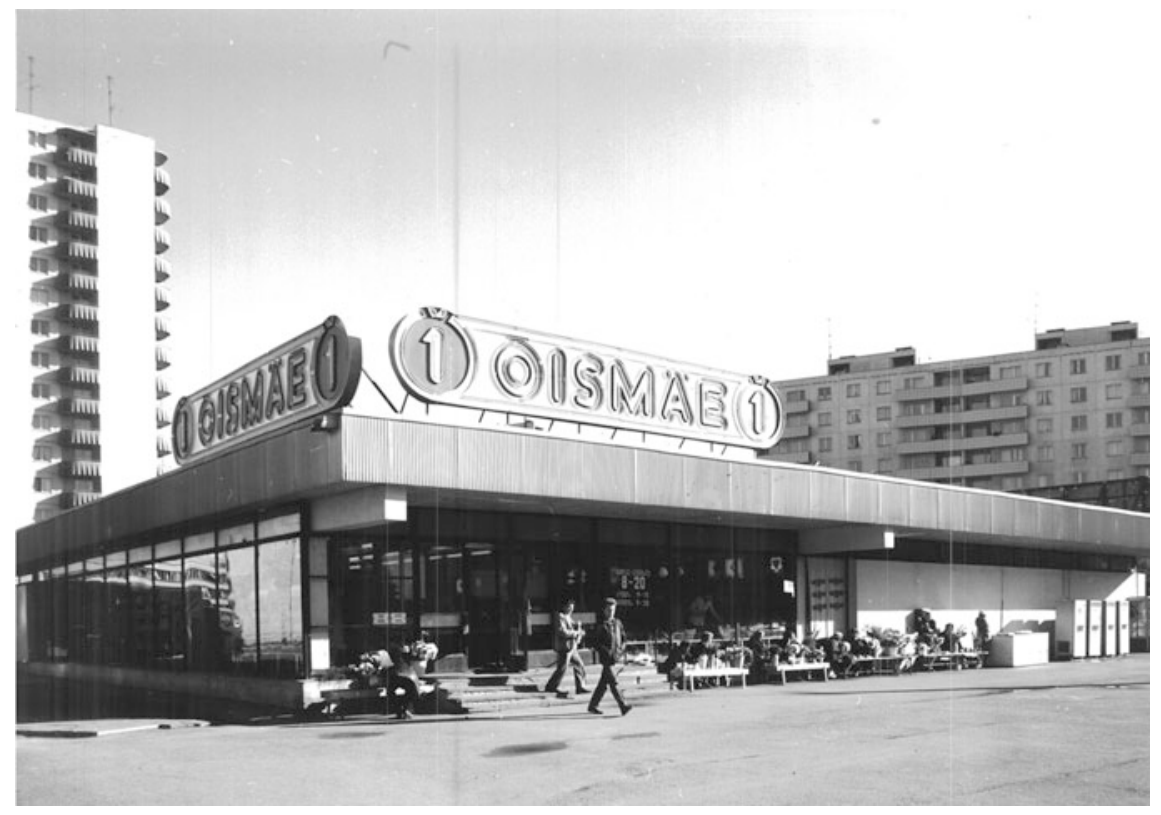

Fig. 13.5 Planned auxiliary shop, later renamed 'Õismäe 1', included in materials submitted for a 1985 architectural award competition Source Tallinn city planning department archive. Used with permission 
given the name 'Õismäe 2'. Another auxiliary grocery was named 'Õismäe 3', and the original Centre No. 3 (later known as Järveotsa Centre in reference to nearby Lake Harku) was completed considerably later. The missing services were gradually integrated with the new network of services (Port 1987). Centre No. 2, the first and only planned centre built, became the main administrative centre of the makrorayon.

\subsubsection{Debates About Socialist Urbanism in the 1970s}

By the late 1970s, half of the residences in Tallinn were built within the previous 15 years. Although new housing construction gradually solved the urgent shortage of living space, the emerging dense and monotonous built environment was something that the residents had never before experienced. Promised service networks remained unfinished, and criticism towards housing estates gained momentum. Despite the limited freedom of expression, the need to complete new residential districts was a topic of public debate in the late 1970s, especially as the city was one of the sites for competitions in the Moscow Olympic games (1980) and the quality of the urban environment was therefore of particular importance. These discussions are best expressed in a series of articles entitled 'City Where We Live' published between 1977 and 1979 in the culture and arts-oriented weekly newspaper 'Sirp ja Vasar'.

Mart Port, one of the most influential architects in Soviet Estonia, argued that 'it is high time to finish our new building complexes without dispersing funding' (Anupõld 1977). He was referring to the incompleteness of Mustamäe and the lack of resources to build needed service centres in Väike-Õismäe. He was of the position that mere rationalisation does not lead to the high quality: 'high level architecture occurs when a good project, builders with good skills, good materials and appropriate funding meet'. He continues 'Also the cars are not sold without wheels. Why, then, should our new residential districts lack public centres, sport facilities, and meeting places? We should give architectural works to people so that they are perfect, finished, and worthy of our era' (Port 1977).

Liimets (1978), an engineer and later a diplomat, is also critical: 'we are already launching housing construction in Lasnamäe, when Väike-Õismäe and even Mustamäe still lack the elementary sport, cultural and service facilities. By 1978, only 5 out of 9 planned mikrorayon centres in Mustamäe have been built'. According to him, certain services are with utmost priority for those population groups who are more confined to their immediate surroundings (children, youth and pensioners).

Fjuk (1979), an architect and journalist and 1990s politician, admits that free planning was a core topic in the twentieth century, but that the socialist countries absorbed only one aspect of it: rationalisation. He argues: 'people naturally seek shelter and safety, however 'wideness' does not offer this quality. An attractive environment should contain contrasts, diversity, surprises and entertainment'. 
According to Fjuk, 'technology prevails' in the Soviet Union: building factories are inflexible, and after production units have been installed, it is difficult to change what they produce. He further claims that the plots between blocks are like 'no-man's-land, an uncivilised milieu, a place of chaos' and that 'the measure of architecture should always be human scale'.

Many opinion leaders called for a more systematic approach to diversify urban housing stock. In 1970, Port (1970) drew attention to the fact that people need dwellings appropriate to various stages of their lifecourse; standards prescribed in plans might therefore be difficult to meet in the future. He proposes that factories should produce building details that could be later reorganised into smaller or larger apartments.

The enemy of ambitions to diversify housing was typically rationalisation. Pihlak (1978), an economic geographer and planner, criticises the decision to omit lower-rise apartment buildings in Väike-Õismäe and condemns criticism of larger dwellings: 'we have only a few large families, and standard apartments in housing estates are not suitable for them'. Also, Paalberg (1978), an economist, advocates the need to accept building single family homes, so that people could contribute to housing construction. Nobody dared to question the system of industrial housing construction. It was proposed that standard projects and rational production of building details should be used for privately constructed single family homes (Bruns 1978a); as the priority was to solve 'the apartment problem', however, the main focus should remain on the construction of high-rise apartment buildings.

Understandably, those responsible for urban development in city offices had a difficult task: they could not ignore the 'rules of the time', but at the same time they were in charge of influential decisions at a period when city grew fast. Chief architect Dmitri Bruns explained (Leetmaa 2017, interview with Dmitri Bruns) how he had to argue with the authorities that Tallinn does not need new factories, since factories would trigger new immigration and additional pressure on already scarce urban housing. But Port also needed to consider the professional critics of his time.

Bruns firmly defended the principle of industrial housing construction (Bruns 1978b): 'the task is to supply residents with apartments and we need to do that consistent with the level of economic development of our society'. He also argues that important aims have been achieved: new apartments contain modern facilities, internal planning of apartments has been improved, families do not share apartments, and equality is considered. According to him, the next crucial updates in quality would be achieved in 1985 within reconstruction of a Housing Construction Factory. Bruns convinces the contemporaries (Bruns 1978a) that the most important challenge is to inspire architects to work together with engineers: 'When architects do not know the logic of production, they only choose from ready-made solutions'. Forty years later, in a retrospective interview, he argues: 'this was not architecture, engineers took over the tasks of architects, partly because the latter were only able to produce houses with pillars and did not adjust to the time' (Leetmaa 2017, interview with Dmitri Bruns).

The Chief Architect admits that the speed of building new service networks has been too slow (Bruns 1978a): 'we are successfully fulfilling the plans as regards 
educational infrastructure, while other services clearly lag behind, most importantly cultural and leisure facilities'. Bruns mentions three reasons for this schism (Bruns 1978c): first, an apartment shortage still exists; second, the capacity of building organisation in the republic has not been increased enough; and third, service buildings are less standardised and more time and workforce is needed to construct them. Bruns offers hope that in time, the ideal service networks will be finished (Bruns 1978c): 'give us some time. Do not demand everything at once'.

\subsubsection{An Incomplete Residential Area Wins the Soviet State Architectural Prize}

A high point for Väike-Õismäe occurred in 1986, when the district was awarded a prestigious Soviet State Architectural Prize. For the competition (Materials Submitted to the Soviet State Architectural Award Competition 1985), VäikeÕismäe was presented as a completed district. Figure 13.6 presents a series of illustrations submitted to the competition. The aerial views of the district were emphasised in various images: the spatial form of the makrorayon, diverse building heights, and reflections of silhouettes in the pond. Organised car parking is situated between residential blocks and public transport uses the circular road.

The award nomination materials include references to both finished and unfinished elements. The educational facilities within the circle - and also district Centre No. 1-are indicated on the scheme. The district milieu is depicted as human scale, with green areas for walking and fishermen angling at the pond or boating in the lake. Kids' activities, relaxation, and everyday activities occur between the residential blocks (rather than parking lots). A healthy mix of nature and urban amenities created an ideal milieu for families.

Mart Port, the head of the Väike-Õismäe planning team, commented in 1987 on the success of the district in the competition: 'the time factor cannot be ignored in the assessment of urban construction. There is always the risk that the solution that seemed persuasive, even unique at the start of the design, turns out to be one of the many and annoying. With Väike-Õismäe, the story was opposite' (Port 1987, 3). According to Port the plan of Väike-Õismäe had opponents, but the exceptions applied were to the benefit of the district. He refers to the makrorayon approach that enabled resource economy; visually appealing and pedestrian-friendly atmospheres; a return to the closed yard design that met the sunlight norms for apartments; use of water features in urban design, etc. Most importantly, Port argues that during the preceding 20 years, urban planning principles changed and this 'worked in favor of Little Oasis Garden' (a nickname that the grand architect gave to Väike-Õismäe) (Port 1987, 6).

Chief Architect Bruns considered how it became possible that an unfinished district won such a prestigious award: 'by this time, of course, quite a lot was finished' (Leetmaa 2017, interview with Dmitri Bruns). Consequently, the 


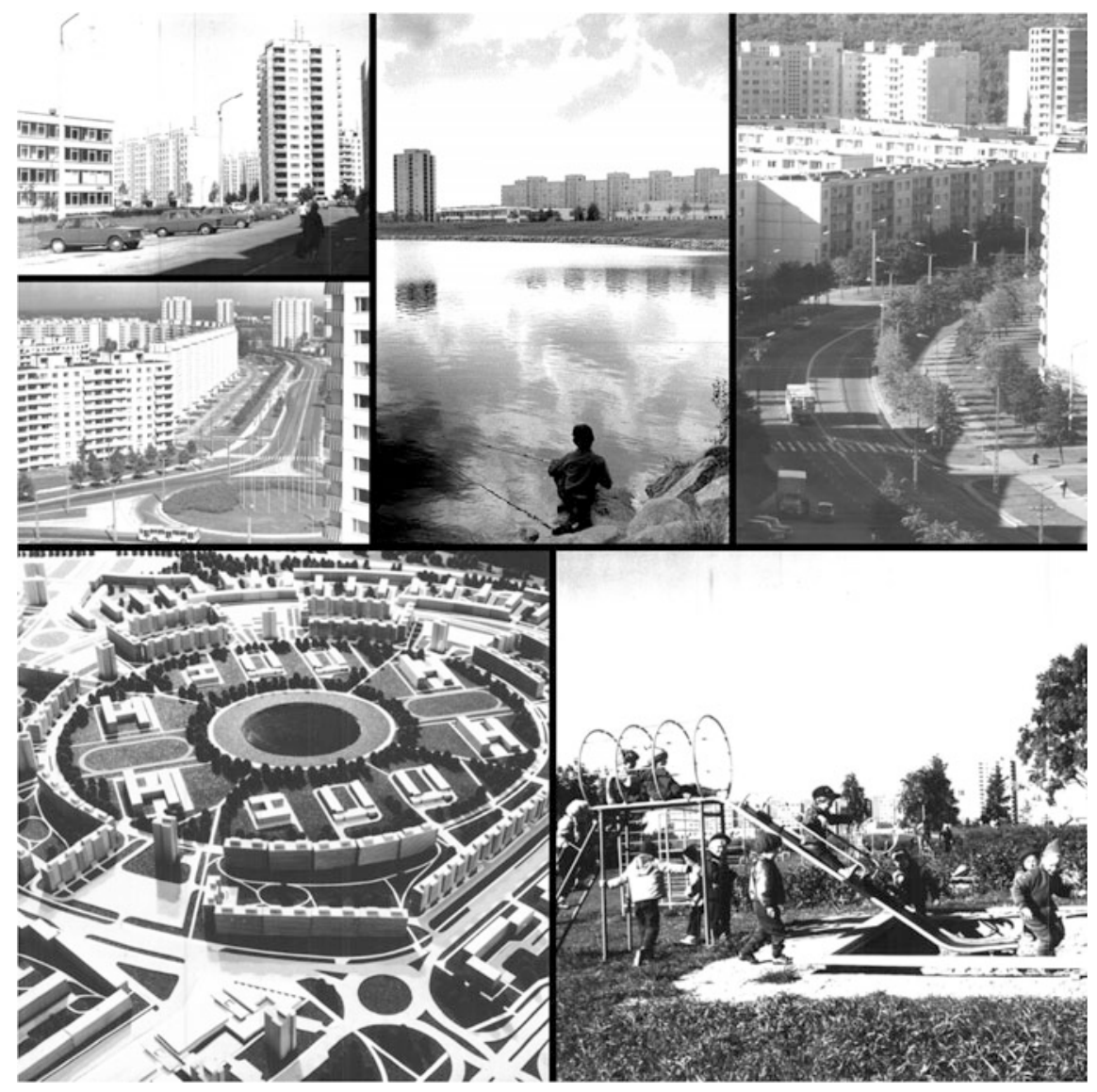

Fig. 13.6 Images of Väike-Õismäe, included in materials submitted for a 1985 architectural award competition Source Tallinn city planning department archive. Used with permission

(in)completeness of socialist housing areas should be considered in relative terms. In his comments on the changes applied in the 1974 Revision compared to the 1968 Detailed Plan, Bruns even diminished the contrasts between two plans, explaining that this was simply an ongoing planning process of a district that started from visions and continued with specifications (Leetmaa 2017, interview with Dmitri Bruns). It follows that at the heyday of socialist housing construction the compromises in the initial plans were de rigueur; with a scarcity of resources, architects' plans still required implementation. 


\subsubsection{Väike-Öismäe Service Networks After the System Change}

When the socialist system collapsed in 1991, Väike-Õismäe, like many other housing estate districts, remained unfinished. No resources were available to complete the plans. Soon, privatisation was initiated and sitting tenants became flat owners and assumed responsibility for care of the buildings and surrounding land.

Väike-Õismäe was a rather prestigious residential environment in the 1990s. Everything created in the previous decades, even if fewer buildings were built than appeared on plans, was new. The decision to locate attractions in this part of Tallinn worked to the benefit of Väike-Õismäe: Rocca al Mare Open Air Museum was opened in 1964 and the Tallinn Zoo was moved adjacent to the district in the 1980s. Compared to Mustamäe, Väike-Õismäe was an advancement in planning principles: apartments had better internal planning, and the structure of the district was logical. The next housing estate district, Lasnamäe (three times larger than Väike-Õismäe), suffered from budget cuts even more and due to intensive immigration also became a symbol of russification.

In 1994, a new revision of Väike-Õismäe district plan (Revision of the District Master Plan of Haabersti, Tallinn, 1994) was adopted, during a time when nobody was able to predict Tallinn's investment capacity. The most striking addition to the district infrastructure was a church building that understandably was not part of typical socialist community networks. The proposed location of the prospective church was iconic - on an island in the middle of the pond (Fig. 13.7). The accompanying note written by the Bishop of the Estonian Evangelic Lutheran Church approves the location but declare that 'in the foreseeable future, no financial tools are available for construction'. The ideas remained on paper only, although in recent years church construction in housing estates became a reality: in 2013, a new orthodox church was opened in Lasnamäe and a brand-new Lutheran church is scheduled to open soon in Mustamäe.

The quest to rename Väike-Õismäe service centres continued into the early 1990 s and reflected an attempt to erase socialist symbols. Instead of simple sequential numbering, the shops were now given names of flowers-Õismäe 1 was renamed Kullerkupu (Trollius europaeus), Õismäe 2 was renamed Nurmenuku (Primula veris), and Õismäe 3 was renamed Meelespea (Myosotis alpestris). These revisions justified the name of Väike-Õismäe district, Little Blossom Hill—and also helped to create the perception that the district is completed.

Today, large commercial chain stores have taken over the commercial space in the makrorayon centres. In addition, one of the largest shopping malls in Tallinn, Rocca al Mare Centre, is located in the corner of the makrorayon where Centre No. 1 was initially planned. A butterfly interchange at this intersection, indicated in the 1968 Detailed Plan, was opened in June 2018. Many other services - a concert hall, car shops, sport halls, cafeterias and pubs - can now be found in the shopping mall or nearby, attracting people from all over the region, but functionally serving 


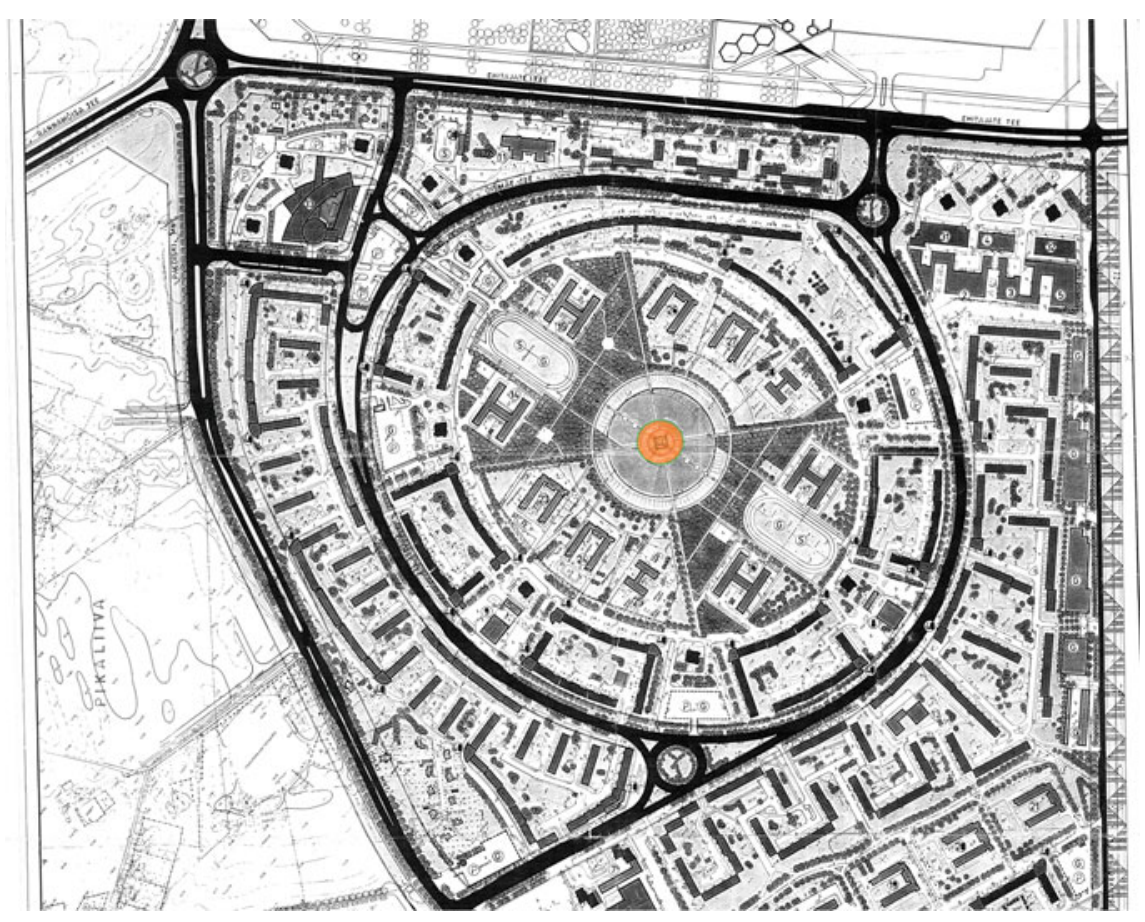

Fig. 13.7 Revision of the district master plan of Haabersti, 1994. Note: No. 44 indicates a proposed church Source Tallinn city planning department archive. Used with permission

also as a contemporary main centre for Väike-Õismäe and nearby fast-growing suburban settlements.

Despite the political system and changing planning ideas, the main centre was eventually established close to its planned location. The only criticism that we can make today is the impacts of these trends to the walkability of the district: higher order services around the districts are accessible today primarily by cars. It seems that the Väike-Õismäe service network has reversed itself over time. The educational infrastructure is still located within the district, as initially planned and realised, but a remarkable share of commercial services, cultural and sport facilities are outside the makrorayon, encouraging car use rather than walking.

Today, housing estates compete with other residential environments in formerly socialist countries (Kovács and Herfert 2012). Although public investments may be directed to housing estates (where a large proportion of the electorate lives) it is increasingly difficult to maintain the relative prestige of these districts (Hess et al. 2018). People with more financial resources prefer gentrifying neighbourhoods or suburbs (Hess et al. 2017; Tammaru et al. 2016) because small and outdated apartments no longer satisfy expectations. The target market for living in housing estates is limited today (Kährik et al. 2019): mostly, younger households at the beginning of their housing careers (usually renters) and older residents who enjoy 
familiar environments. Walkability, service availability, greenery, recreation spaces, and even its socialist past could help Väike-Õismäe maintain its social status, provided that a systematic approach is made by contemporary planners to make good use of these aspects. Still, a pedestrian experience in Väike-Õismäe today can give an impression of urban abandonment.

\subsection{Conclusion}

A hallmark of the Soviet Union was that many promises of better lives ahead for Soviet citizens were in reality unfulfilled. The same phenomenon occurred in city planning - initial visions for urban plans were not fully realised. Although there was an ambition to build cities with complexity and scientific rationale, many Soviet citizens lived in 'unfinished cities' due to resource limitations and other inefficiencies of the Soviet system. But the problem is not unique to specific places (the republics of the Soviet Union) or times (the era of state socialism); we live today within a market economy in which we masterplan cities without being able to predict the interests of investors and long-term outcomes.

From the evolution of Väike-Õismäe-from approval of its plan in 1968 through construction and residence to today, nearly three decades since the end of state socialism - we learn that compromises in service networks were made in the very first phases of implementation of plans before construction activity was launched. While previous scholarly literature argues that approved plans for housing estates simply remained unfinished, this study clarifies circumstances and outcomes: initial detailed plans merely demonstrated the professionalism of Soviet architects, while subsequent revisions of plans adopted the realities of the socialist urban economy and funding realities.

The planning and construction of Väike-Õismäe suggests that other socialist housing estates likely faced similar limitations. Otherwise, an unfinished housing estate could not have been awarded one of the most prestigious architectural prizes in the Soviet Union. We conclude that (in)completeness vis-à-vis initial visions was not an argument during the award of architectural prizes. Instead, the honour of an award recognised the skills of key persons to oversee the construction of housing estates under budgetary restrictions in an inflexible system so that the resulting environment will still become a coherent whole. Another interpretation is that recognition in the Soviet Union-expressed through the honour of architectural prizes - also enabled the legitimisation of modernist housing estates and communicated to Soviet citizens that newly erected housing estates were residential environments suitable for housing workers and their families and accommodated the ideological aims of state socialism including homogeneity, classlessness, and equality. 
Acknowledgments This project has received funding from the European Union's Horizon 2020 research and innovation programme under Marie Skłodowska-Curie grant agreement No. 655601. The authors are grateful to Mr. Dmitri Bruns, the Chief Architect of Tallinn 1960-1980, whose retrospective memoirs and interpretations of the socialist urban planning led us to a deeper understanding of the era that we have not had chance to experience personally. The authors acknowledge helpful contributions to the research from Pille Metspalu, Johanna Holvandus and Annika Väiko.

\section{References}

Andrusz G (1984) Housing and urban development in the USSR. SUNY Press, Albany, New York Anupõld E (1977) A group discussion about new city. City Where We Live. Sirp ja Vasar 7 (1):89

Bater JH (1980) The Soviet city: ideal and reality. Edward Arnold, London, UK

Bruns D (1978a) To continue the debate. City Where We Live. Sirp ja Vasar 27(4):16

Bruns D (1978b) To continue the debate... City Where We Live. Sirp ja Vasar 13(4):8-9

Bruns D (1978c) To continue the debate... City Where We Live. Sirp ja Vasar 20(4):16

Bruns D (1993) Tallinn urban development. Valgus, Tallinn

Bruns D (2007) Tallinna peaarhitekti mälestusi ja artikleid. Eesti Arhitektuurimuuseum, Tallinn

Cinis A, Dremaite M, Kalm M (2008) Perfect representation of Soviet planned space: mono-industrial towns in the Soviet baltic republics in the 1950s-1980. Scandanavian J Hist 33(3):226-246

Dahir J (1947) The neighbourhood unit plan: its spread and acceptance. Russell Sage Foundation, New York, NY

De Decker P, Newton C (2009) At the fall of Utopia. Urban izziz/Urban Chall 20:74-82

DiMaio AJ (1974) Soviet urban housing: problems and policies. Praeger, New York

Fjuk I (1979) Understanding new urbanism. City Where We Live. Sirp ja Vasar 1(5):16

French RA, Hamilton FEI (1979) The socialist city: spatial structure and urban policy. Wiley, London

Gentile M (2004) Former closed cities and urbanisation in the FSU: an exploration in Kazakhstan. Eur-Asia Stud 56(2):263-278

Gentile M, Sjöberg Ö (2006) Intra-urban landscapes of priority: the Soviet legacy. Eur-Asia Studies 58(5):701-729

Goss A (1961) Neighbourhood units in British new towns. Town Plan Rev 32(1):66-82

Hall DR (1987) Emerging residential structures of socialist cities. Contemp City Ecol 6:257-278

Hall P (1988) Cities of tomorrow. An intellectual history of urban planning and design in the twentieth century. Basil Blackwell, Oxford

Hatherley O (2016) Landscapes of Communism: a history through buildings. The New Press, England

Hausladen G (1987) Planning the development of the socialist city: the case of Dubna New Town. Geoforum 18(1):103-115

Hegedüs J, Tosics I (1983) Housing classes and housing policy: some changes in the Budapest housing market. Int J Urban Reg Res 7(4):467-494

Hess DB (2017) Decrypting Fareless Public Transport in Tallinn, Estonia. Case Stud Transp Policy 5(4):690-698

Hess DB (2018) Transport in Mikrorayons: accessibility and proximity to centrally planned residential districts during the socialist era, 1957-1989. J Plan Hist 17(3):184-204

Hess DB, Hiob M (2014) Preservation by neglect in Soviet-era town planning in Tartu, Estonia. J Plan Hist 13(1):24-49 
Hess DB, Iacobucci E, Väiko A (2017) Network connections and neighborhood perception: using social media postings to capture attitudes among twitter users in Estonia. J Archit Urban Plan 13:67-77. https://doi.org/10.1515/aup-2017-0010

Hess DB, Tammaru T, van Ham M (2018) Lessons learned from a Pan-European study of large housing estates: origin, trajectories of change, and future prospects. In: Hess DB, Tammaru T, Van Ham M (eds) Housing estates in Europe: poverty, segregation, and policy challenges. Springer, Dordrecht, The Netherlands

Kalm M (2012) An apartment with all conveniences' was no panacea: mass housing and the alternatives in the Soviet period in Tallinn. Architektura and Urbanizmus 46(3-4):194-207

Kaufmann EC (1936) Neighbourhood units as new elements of town planning. J R Inst Br Archit 44:165-175

Kovács Z, Herfert G (2012) Development pathways of large housing estates in post-socialist cities: an international comparison. Hous Stud 27(3):324-342. https://doi.org/10.1080/02673037. 2012.651105

Kährik A, Kangur K, Leetmaa K (2019) Socio-Economic and ethnic trajectories of housing estates in Tallinn, Estonia. In: Hess DB, Tammaru T (eds) Housing estates in the Baltics: the legacy of central planning in Estonia, Latvia, and Lithuania. Springer, Dordrecht, The Netherlands

Leetmaa K (2017) Interview with Dmitri Bruns-Tallinn chief architect in the years 1960-1980

Liepa-Zemeša M, Hess DB (2016) Effects of public perception on urban planning: evolution of an inclusive planning system during Crises in Latvia. Town Plan Rev 87(1):71-92

Liimets E (1978) Phenomena associated with urbanisation. City Where We Live. Sirp ja Vasar $11(8): 12$

Lu D (2006) Travelling urban form: the neighbourhood unit in China. Plan Perspect 21(4): 369-392

Marcuse P (1996) Privatization and its discontents: property rights in land and housing in the transition in Eastern Europe. In: Andrusz G, Harloe M, Szelènyi I (eds) Cities after socialism: urban and regional change and conflict in post-socialist societies. Blackwell Publishers, Oxford

Marozas M (2009) Post-Socialist city: adaptation of USSR-Made urban structures in Lithuania. Delft University of Technology, The Netherlands

Materials Submitted to the Soviet State Architectural Award Competition (1985) Archive of the Tallinn city planning department

Metspalu P, Hess DB (2018) Revisiting the role of architects in planning large-scale architects in planning large-scale housing in the USSR: the birth of socialist residential districts in Tallinn, Estonia, 1957-1979. Plan Perspect 1-27

Miliutin NA (1974) Sotsgorod: the problem of building socialist cities. MIT Press

Monclús J, Díez Medina C (2016) Modernist housing estates in Europe-an cities of the Western and Eastern Blocs. Plan Perspect 31(4):533-562

Obraztsov A (1961) What will our future cities look like? Sov Rev 2(4):34-37

Paalberg H (1978) The problems of the development of Tallinn. Eesti Raamat, Tallinn

Perry CA (1926) The local community as a unit in the planning of urban residential areas. In: Perry CA (ed) The urban community. University of Chicago Press, Chicago, pp 238-241

Perry CA (1929) Regional survey of New York and its environs, vol VII. Neighborhood and community planning. vol VII. Committee on regional plan of New York and its Environs, New York, NY

Pihlak Ü (1978) City where we live. Sirp ja Vasar 1(9):9

Port M (1966) England through the eyes of an architect. Eesti Raamat, Tallinn

Port M (1970) Architecture needs science! Sirp ja Vasar 15(5):3

Port M (1977) Speeches of a plenum. Sirp ja Vasar 28(10):7-8

Port M (1987) Väike-Õismäest ja Ajategurist. Ehitus ja Arhitektuur 2

Robinson J (2009) The Post-Soviet city: identity and community development. Paper presented at the city futures in a globalising world: an international conference on globalism and urban change, Madrid, Spain

Shaw DJB (1991) The past, present, and future of the Soviet city plan. Plan Perspect 6:125-138

Shenker I (1971) City surprising to four Russian architects. New York Times, New York 
Sjöberg Ö (1992) Underurbanisation and the zero urban growth hypothesis: diverted migration in Albania. Geografiska Annaler Ser B Hum Geogr 74(1):3-19

Smith DM (1996) The Socialist City. In: Andrusz G, Harloe M, Szelènyi I (eds) Cities after socialism: urban and regional change and conflict in post-socialist societies. Blackwell Publishers, Oxford

Stanilov K (2007) Nine Housing Trends in Central and Eastern European Cities During and After the Period of Transition. In: Stanilov K (ed) The Post Socialist City. Urban form and space transformations in central and eastern Europe after Socialism, Springer, Heidelberg, pp 173-190

Svetlichnyi B (1960) Soviet town planning today. Probl Econ 111(8):29-36

Šiupšinskas M, Lankots E (2019) Collectivist ideals and consumer spaces: microrayon centres in Vilnius and Tallinn. In: Hess DB, Tammaru T (eds) Housing estates in the Baltics: the legacy of central planning in Estonia, Latvia, and Lithuania. Springer, Dortrecht, The Netherlands

Tammaru T, Marcińczak S, van Ham M, Musterd S (2016) Socio-Economic segregation in European capital cities: east meets west. Routledge, New York/London

Temelová J, Novák J, Ouředníček M, Puldová P (2011) Housing estates after socialism: various trajectories and inner differentiation. Urban Stud 48(9):1811-1834. https://doi.org/10.1177/ 0042098010379279

Tsenkova S (2009) The legacy of socialist housing systems. In: Tsenkova S (ed) Housing policy reforms in post socialist Europe: lost in transition. Physica-Verlag, Heidelberg, Germany

White PM (1980) Soviet urban and regional planning. St. Martin's Press, London, UK

Wright HM (1958) A visit to Russia. Town Plan Rev 29(3):162-178

Open Access This chapter is licensed under the terms of the Creative Commons Attribution 4.0 International License (http://creativecommons.org/licenses/by/4.0/), which permits use, sharing, adaptation, distribution and reproduction in any medium or format, as long as you give appropriate credit to the original author(s) and the source, provide a link to the Creative Commons license and indicate if changes were made.

The images or other third party material in this chapter are included in the chapter's Creative Commons license, unless indicated otherwise in a credit line to the material. If material is not included in the chapter's Creative Commons license and your intended use is not permitted by statutory regulation or exceeds the permitted use, you will need to obtain permission directly from the copyright holder.

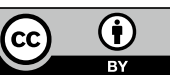

